\title{
Autogenous mucochondral-osteal nasoseptal graft for reconstruction of orbital floor: a preliminary study
}

\author{
B. M. Rudagi, Rishabh Jain*, Shahbaaz Naikwade, Gaurav Bhavar
}

Department of Oral and Maxillofacial Surgery, ACPM Dental College and Hospital, Dhule, Maharashtra, India

Received: 01 July 2021

Revised: 13 August 2021

Accepted: 16 August 2021

\author{
*Correspondence: \\ Dr. Rishabh Jain, \\ E-mail: rishabhjain78632@gmail.com
}

Copyright: (c) the author(s), publisher and licensee Medip Academy. This is an open-access article distributed under the terms of the Creative Commons Attribution Non-Commercial License, which permits unrestricted non-commercial use, distribution, and reproduction in any medium, provided the original work is properly cited.

\begin{abstract}
Resection of malignant sinonasal/skull base tumors that erode the orbital floor often result in large defects. We describe a technique for orbital floor reconstruction using a structural pedicled mucochondral-osteal nasoseptal flap (PMCONSF) that includes both soft tissue and bony-cartilaginous components with a continuous pedicled vascular supply. Case presentation was 11 patients having tumors associated with midface requiring maxillectomy and removal of inferior wall of orbit were included. Reconstruction of floor of orbit was done using PMCONSF. Post-operative outcomes of the techniques were studied. In all 11 cases reconstruction of floor of orbit was done using pedicled nasoseptal cartilage and in none of the cases communication of the orbital content with maxillary sinus was encountered. Complete ophthalmic examination revealed no significant diplopia, no entrapment of ocular structures with good ocular motility. Adequate reconstruction of the orbital floor is crucial to maintaining long-term ocular function. The PMCONSF offers great flexibility in flap design as well as a high rate of success. The bony-cartilaginous component offers a rigid structural part to the orbital floor, eliminating the functional defects that can occur from anatomical changes. The pedicled vascular supply helps assist in graft integration, limiting the potential for graft rejection or necrosis following postoperative radiotherapy. We believe that this graft offers a viable alternative to existing methods for orbital reconstruction in patients with large orbital floor defects, especially for cases in which adjuvant postoperative radiotherapy is anticipated.
\end{abstract}

Keywords: Nasoseptal graft, Maxillectomy, Malignant tumors, Maxillofacial, Pedicled graft

\section{INTRODUCTION}

Resection of malignant sinonasal/skull base tumors that erode the orbital floor often result in large defects. Unrepaired orbital floor defects can lead to enophthalmos, hypoglobus or herniation of orbital contents, with subsequent atrophy of herniated fat and muscle. ${ }^{1,2,4}$

These defects are not only disfiguring, but may result in significant complications such as diplopia or infection. The goals of orbital floor reconstruction are to decrease functional deficits, provide support for orbital contents, restore orbital floor continuity, and prevent the herniation of orbital contents into the maxillary or ethmoidal sinuses. Furthermore, for cases in which the orbital floor defect results from malignancy, incorporating a structural graft with the potential to withstand post-operative radiotherapy is important for long-term viability.,

Numerous methods for orbital floor reconstruction have been proposed, including alloplastic grafts, free-tissue flaps, and vascularized flaps. We describe a technique for orbital floor reconstruction using a structural pedicled mucochondral-osteal nasoseptal flap (PMCONSF) that includes both soft tissue and bony-cartilaginous components with a continuous pedicled vascular supply. ${ }^{6,8}$ 
This unique flap provides an autologous solution for reconstruction and thus, avoids the use of foreign implants. ${ }^{7,9}$ We believe that this graft offers a unique combination of benefits by offering structural support of the orbital floor, reducing the risk of infection by providing a barrier from the paranasal sinuses, and potentially withstanding postoperative radiotherapy because of its robust vascularity.

\section{CASE SERIES}

\section{Harvest of the nasal septal graft}

The graft is harvested following conventional Weber Fergusson approach for maxillectomy exposing the entire structure. This graft is essentially an extension of the traditional vascularized pedicled nasoseptal flap (PNSF) commonly used for repair of skull base defects. The standard PNSF was modified by keeping this flap attached to the bony-cartilaginous septum. A Killian incision was made ipsilaterally, and the contralateral mucoperichondrial/mucoperiosteal flap was elevated. Four bony-cartilaginous cuts to release the structural component of the flap were made (Figure 1); anterior (vertical cartilaginous cut), superior (horizontal bonycartilaginous cut), inferior (horizontally, by dividing the quadrangular cartilage articulation with the maxillary crest anteriorly, and by cutting through the vomer posteriorly), and posterior (vertical bony cut through the vomer, anterior to the face of the sphenoid).The harvested PMCONSF was subsequently rotated into the surgical defect site, with the mucosal side facing the maxillary sinus and the bony-cartilaginous component used as the orbital floor. The PMCONSF was secured to the periosteum of the remnant orbital rim using 3-0 Vicryl sutures. The maxillectomy defect was closed in the standard fashion. 11 patients having tumors associated with midface requiring maxillectomy and removal of inferior wall of orbit were included (Table 1). Reconstruction of floor of orbit was done using Pedicled nasoseptal flap. Postoperative outcomes of the techniques were studied. In all 11 cases reconstruction of floor of orbit was done using pedicled nasoseptal cartilage and in none of the cases communication of the orbital content with maxillary sinus was encountered. Viability of the pedicled flap was intact in the postoperative period with no evidence of infection or necrosis. No significant Enophthalmos was encountered in the postoperative phase with good support to the orbital content. Complete ophthalmic examination revealed no significant diplopia, no entrapment of ocular structures with good ocular motility. Protrusion of graft was encountered in one case which required postoperative correction. Defect due to maxillectomy was filled with temporalis myofascial flap which gives good bulk in the area, restoration of the orbital floor by PNSF altogether led to good esthetic results.

Table 1: Maxillectomy and removal of inferior wall of orbit.

\begin{tabular}{|c|c|c|c|c|c|c|c|}
\hline Patients & Enophthalmos & Diplopia & $\begin{array}{l}\text { Restriction } \\
\text { of ocular } \\
\text { motility }\end{array}$ & $\begin{array}{l}\text { Graft } \\
\text { protrusion }\end{array}$ & $\begin{array}{l}\text { Post-op } \\
\text { esthetic }\end{array}$ & $\begin{array}{l}\text { Flap } \\
\text { viability } \\
\text { post } \\
\text { radiation }\end{array}$ & $\begin{array}{l}\text { Communication } \\
\text { with maxillary } \\
\text { sinus }\end{array}$ \\
\hline 1. & Not significant & $\begin{array}{l}\text { Not } \\
\text { significant }\end{array}$ & No restiction & $\begin{array}{l}\text { Graft in } \\
\text { place }\end{array}$ & Good & Flap viable & Not significant \\
\hline 2. & Not significant & $\begin{array}{l}\text { Not } \\
\text { significant }\end{array}$ & No restriction & $\begin{array}{l}\text { Graft in } \\
\text { place }\end{array}$ & Good & Flap viable & Not significant \\
\hline 3. & Not significant & $\begin{array}{l}\text { Not } \\
\text { significant }\end{array}$ & No restriction & $\begin{array}{l}\text { Graft in } \\
\text { place }\end{array}$ & Good & Flap viable & Not significant \\
\hline 4. & Not significant & $\begin{array}{l}\text { Not } \\
\text { significant }\end{array}$ & No restriction & $\begin{array}{l}\text { Graft in } \\
\text { place }\end{array}$ & Good & Flap viable & Not significant \\
\hline 5. & Not significant & $\begin{array}{l}\text { Not } \\
\text { significant }\end{array}$ & No restriction & $\begin{array}{l}\text { Significant } \\
\text { Protrusion }\end{array}$ & Good & Flap viable & Not significant \\
\hline 6. & Not significant & $\begin{array}{l}\text { Not } \\
\text { significant }\end{array}$ & No restriction & $\begin{array}{l}\text { Graft in } \\
\text { place }\end{array}$ & Good & Flap viable & Not significant \\
\hline 7. & Not significant & $\begin{array}{l}\text { Not } \\
\text { significant }\end{array}$ & No restriction & $\begin{array}{l}\text { Graft in } \\
\text { place }\end{array}$ & Good & Flap viable & Not significant \\
\hline 8. & Not significant & $\begin{array}{l}\text { Not } \\
\text { significant }\end{array}$ & No restriction & $\begin{array}{l}\text { Graft in } \\
\text { place }\end{array}$ & Good & Flap viable & Not significant \\
\hline 9. & Not significant & $\begin{array}{l}\text { Not } \\
\text { significant }\end{array}$ & No restriction & $\begin{array}{l}\text { Graft in } \\
\text { place }\end{array}$ & Good & Flap viable & Not significant \\
\hline 10. & Not significant & $\begin{array}{l}\text { Not } \\
\text { significant }\end{array}$ & No restriction & $\begin{array}{l}\text { Graft in } \\
\text { place }\end{array}$ & Good & Flap viable & Not significant \\
\hline 11. & Not significant & $\begin{array}{l}\text { Not } \\
\text { significant }\end{array}$ & No restriction & $\begin{array}{l}\text { Graft in } \\
\text { place }\end{array}$ & Good & Flap viable & Not significant \\
\hline
\end{tabular}




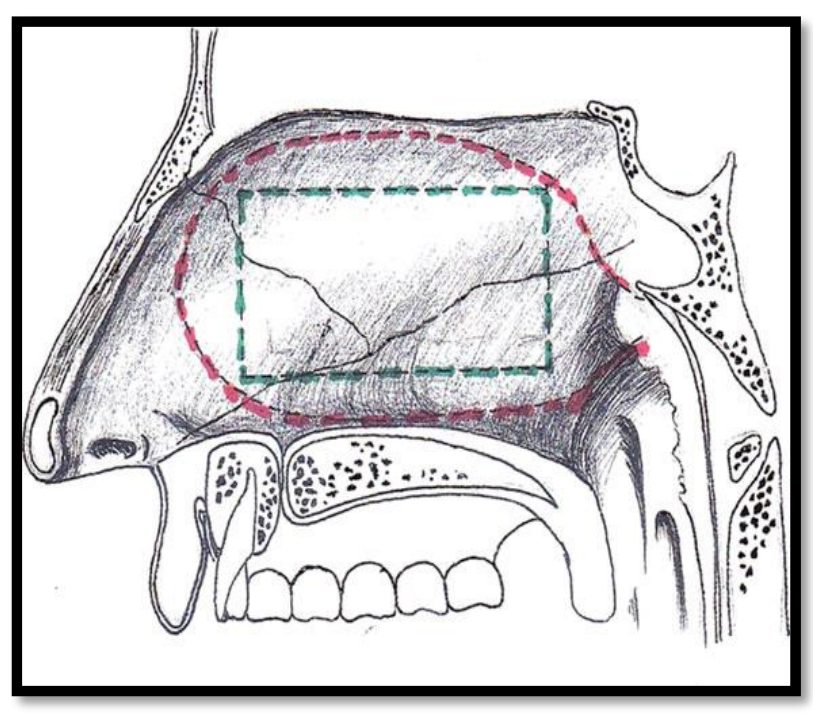

Figure 1: Mucosal incisions (red dotted line) and cartilaginous-bony cuts (green dotted line).

\section{DISCUSSION}

Adequate reconstruction of the orbital floor is crucial to maintaining long-term ocular function. Lack of sufficient rigid reconstruction of the orbital floor is associated with an increased risk of enophthalmos, hypoglobus, diplopia, and disturbances of extraocular muscle function. Incomplete reconstruction may also result in ectropioninduced lid malposition and exposure keratitis.

The need for rigid floor reconstruction is typically determined by the size of the defect. Small orbital floor defects or isolated medial or lateral wall defects usually do not require reconstruction. Slightly larger defects in the orbital floor can be repaired with a thick fascial sling tightly secured to the margins of the defect.

However, subtotal ( $>80 \%$ of the surface area), total, or multi-segmental defects including the floor and 1 or more walls typically require aggressive rigid reconstruction. A number of methods for orbital floor reconstruction have been proposed. Most of the published data concerning reconstruction of orbital floor defects pertains to reconstruction of orbital floor fractures, which typically involves the use of alloplastic materials owing to their availability and convenience of use.

Alloplastic reconstruction of the rigid component of the orbital floor is performed using titanium or a synthetic mesh, usually polyethylene or polypropylene. Polyethylene implants such as Medpor are becoming popular as both an alternative and an addition to titanium allografts. They have the advantage of being able to promote fibrovascular ingrowth and mucosalization, provide additional structural support, and maintain the local host's immune response within the implant, offering infection resistance. Additionally, with alloplastic grafts, a second operative site is not needed to harvest an autologous graft. However, synthetic materials can be associated with extensive scarring, resulting in movement restriction, increased risk of infection, high cost of graft procurement, and graft extrusion. Additionally, given that these grafts tend to be relatively thin, a free soft-tissue or pedicled muscle flap is often required for complete reconstruction of the orbit.

Nasal septal cartilage alone has been used previously as a free graft for reconstruction. It is a semi-rigid autogenous material that is easily accessible with better biocompatibility and less risk of extrusion or infection compared with alloplastic grafts. Although several studies have demonstrated adequate repair using septal cartilage as a free graft, it theoretically relies on local tissue for its blood supply and may become ischemic and necrose in the postoperative period. $^{5,11}$ An important aspect in reconstruction is the need for postoperative radiotherapy, as it can impact graft healing, integration, and long-term viability.

Post-implant irradiation of non-vascularized bone grafts is associated with significant inhibition of bone in growth and mineral apposition, resulting in poor bone healing and stability. Vascularized bone grafts have been shown to have higher success rates compared to non-vascularized grafts when used for primary reconstruction in patients needing postoperative radiotherapy, making them the graft of choice for these patients. The PNSF, consisting of mucoperichondrium and mucoperiosteum, is routinely used as an effective flap in skull base reconstruction. It is durable and has a very robust vascular supply when compared to previously described septal rotational flaps. ${ }^{7-}$

The PNF offers great flexibility in flap design as well as a high rate of success. However, the PNSF does not incorporate a structural rigid component. In 1983, Siemssen and Siemssen reported repair of the orbital floor using transposition of the septal wall hinged on the contralateral mucous membrane as a local flap after subtotal maxillectomy. This technique, however, results in a subtotal septal perforation because the ipsilateral mucous membrane is sacrificed. Our patient required rigid reconstruction of the orbital floor due to a large bony and soft tissue defect. Furthermore, we wanted to eliminate any communication between the sinuses and the periorbital contents, and integrate a structural repair that could withstand postoperative radiotherapy. We felt that the patient would benefit most from a large, rigid, pedicled, vascularized bony-cartilaginous graft with a soft tissue component. The PMCONSF accomplishes all of these objectives. The bony-cartilaginous component offers a rigid structural part to the orbital floor, eliminating the functional defects that can occur from anatomical changes. ${ }^{5,10,11}$

The mucosal lining integrates with the surrounding mucosa, sealing off the nasal cavity from the orbit and limiting the risk of infection. The pedicled vascular supply 
helps assist in graft integration, limiting the potential for graft rejection or necrosis following postoperative radiotherapy. This graft is also easily accessible during the endoscopic endonasal part of the procedures, obviating the need for additional surgical sites to harvest autologous graft components.

We believe that this graft offers a viable alternative to existing methods for orbital reconstruction in patients with large orbital floor defects, especially for cases in which adjuvant postoperative radiotherapy is anticipated.

\section{CONCLUSION}

Resection of sinonasal/skull base tumors may require orbital floor reconstruction to limit cosmetic and functional deficits. The use of vascularized grafts for orbital floor reconstruction has been associated with improved integration and healing, especially in patients requiring postoperative radiotherapy. We proposed a structural mucochondral-osteal nasoseptal flap for repair of these defects. PMCONSF is a versatile and reliable option for orbital floor reconstruction.

Funding: No funding sources

Conflict of interest: None declared

Ethical approval: Not required

\section{REFERENCES}

1. Sharma SK, Sawangdee Y, Sirirassamee B. Access to health: women's status and utilization of maternal health services in Nepal. $J$ Biosoc Sci. 2007;39(5):671-92.

2. Li KK. Repair of traumatic orbital wall defects with nasal septal cartilage: report of five cases. J Oral Maxillofac Surg. 1997;55(10):1098-102.

3. Suárez C, Ferlito A, Lund VJ, Silver CE, Fagan JJ, Rodrigo JP, et al. Management of the orbit in malignant sinonasal tumors. Head Neck. 2008;30(2):242-50.

4. Bayat M, Heravi F, Khalilzadeh O, Mirhosseni Z, Tari A. Comparison of conchal cartilage graft with nasal septal cartilage graft for reconstruction of orbital floor blowout fractures. Br J Oral Maxillofac Surg. 2010;48(8):617-20.

5. Lai A, Gliklich RE, Rubin PA. Repair of orbital blow-out fractures with nasoseptal cartilage. Laryngoscope. 1998;108(5):645-50.

6. Jegoux F, Malard O, Goyenvalle E, Aguado E, Daculsi G. Radiation effects on bone healing and reconstruction: interpretation of the literature. Oral Surg Oral Med Oral Pathol Oral Radiol Endod. 2010;109(2):173-84.

7. Liu JK, Schmidt RF, Choudhry OJ, Shukla PA, Eloy JA. Surgical nuances for nasoseptal flap reconstruction of cranial base defects with high-flow cerebrospinal fluid leaks after endoscopic skull base surgery. Neurosurg Focus. 2012;32(6):7.

8. Eloy JA, Shukla PA, Choudhry OJ, Singh R, Liu JK. Challenges and surgical nuances in reconstruction of large planum sphenoidale tuberculum sellae defects after endoscopic endonasal resection of parasellar skull base tumors. Laryngoscope. 2013;123(6):135360.

9. Eloy JA, Choudhry OJ, Christiano LD, Ajibade DV, Liu JK. Double flap technique for reconstruction of anterior skull base defects after craniofacial tumor resection: technical note. Int Forum Allergy Rhinol. 2013;3(5):425-30.

10. Eloy JA, Patel AA, Shukla PA, Choudhry OJ, Liu JK. Early harvesting of the vascularized pedicled nasoseptal flap during endoscopic skull base surgery. Am J Otolaryngol. 2013;34(3):188-94.

11. Talesh KT, Babaee S, Vahdati SA, Tabeshfar Sh. Effectiveness of a nasoseptal cartilaginous graft for repairing traumatic fractures of the inferior orbital wall. Br J Oral Maxillofac Surg. 2009;47(1):10-3.

Cite this article as: Rudagi BM, Jain R, Naikwade S, Bhavar G. Autogenous mucochondral-osteal nasoseptal graft for reconstruction of orbital floor: a preliminary study. Int J Otorhinolaryngol Head Neck Surg 2021;7:1517-20. 